\title{
ISSR Analysis for Determination of Genetic Diversity and Relationship in Eight Turkish Olive (Olea europaea L.) Cultivars
}

\author{
Ergun KAYA ${ }^{1,2}$ \\ ${ }^{1}$ Mugla Sitki Kocman University, Faculty of Science, Molecular Biology and Genetics Department, Kotekli, 48000, Mugla, Turkey; ergunkaya@mu.edu.tr \\ ${ }^{2}$ Gebze Technical University, Molecular Biology and Genetics Dept, 41400, Gebze, Kocaeli, Turkey
}

\begin{abstract}
Olive cultivar identification is very important especially for fruit productivity and olive oil quality. Up to date, numerous techniques have been used for characterization of olive cultivars and detection of genetic variability. In the present study, 40 clones specific to Turkey (8 cultivars, each having 5 clones) were assessed for cultivar determination via inter simple sequence repeat (ISSR) marker systems using 10 ISSR primers. In total, 217 band profiles were obtained, 206 of which were polymorphic (94.9\% polymorphism). The cultivars were segregated into two main clusters, each cluster being subdivided into two groups, while all the clones of a cultivar belong to the same main cluster. The only exception was the distribution of the clones of cultivar 'Tekir': 'Tekir 1', 'Tekir 2' and 'Tekir 3' on cluster III, while 'Tekir 4' and 'Tekir 5' were on cluster IV, therefore grouped into different main clusters. In the present study, ISSR analysis displayed a high level of genetic variability among Turkish olive cultivars, indicating a potential resource for the use of this germplasm in clonal selection programs.
\end{abstract}

Keywords: cluster, ISSR, molecular marker, polymorphism, variability

\section{Introduction}

Olive (Olea europea L.), with more than 2,600 cultivars, is one of the oldest cultivated plants characteristic of the Mediterranean area, where it is the most important oil-producing crop (Bartolini et al. 2005; Rugini and Lavee, 1992; Zohary and Hopf, 1994). It is determined in two forms, former is wild (O. europaea subsp. europaea var. sylvestris) and the latter is cultivated (O. europaea subsp. europaea var. europaea). The cultivated olive (O. europaea L. var. europaea $)$ is propagated by cutting or grafting, whereas wild olive $(O$. europaea $\mathrm{L}$. var.sylvestris) is reproduced from seeds (Green, 2002).

Olive trees have a high level of heterozygosity and genetic polymorphism is common among cultivars, so that they are predominantly allogamus (Angiolillo et al, 1999; Diaz et al., 2006; Rallo et al, 2000). This variability, coupled with the confusion in olive cultivar nomenclature, make necessary the evaluation and characterization of olive genetic resources that have been recognised as very important, since both olive productivity and oil quality are traits inherent to a variety (Fiorino and Rallo, 1999).

Inter simple sequence repeat (ISSR) markers have been effectively used to identify genetic variation among some olive cultivars (Gomes et al, 2008; Martins-Lopes et al, 2007; MartinsLopes et al, 2009; Terzopoulos et al, 2005). ISSRs are repeated sequence motifs that are ubiquitously distributed throughout the plant genome. They can be easily amplified by PCR reactions using DNA nucleotide primers, the unique sequences flanking the repeated motifs. Polymorphic DNA fragments can be produced due to differences in the number of the repeat units. A number of ISSR markers have already been developed in olive and their primer sequences have been published (Hess et al., 2000; Gemas et al., 2004).

Determination of genetic relationships among cultivars eases efficient sampling, operating and using of germplasm resources. This study aims to determination of genetic diversity and relationship in fourty Turkish olive (Olea europaea L.) clones belonging to eight cultivars via inter simple sequence repeat (ISSR) marker systems using ten ISSR primers.

\section{Materials and methods}

\section{Plantmaterial}

Fourty olive clones belonging to eight different olive cultivars ('Edincik', 'Gemlik', 'Edremit', 'Halhali', 'Domat', 'Alacam', 'Tekir' and 'Yaglik') were analysed. All samples were obtained from different parts of Turkey: Black Sea, Aegan (obtained from Aquaculture Central Research Institute), Izmir, Mediterranean and Southeast Anatolia.

\section{DNA extraction}

The total genomic DNA was extracted by using CTAB method (Doyle and Doyle, 1987) by grinding the young leaf tissue to a fine powder. DNA sample concentration was determined using a nanodrop spectrophotometer (BioSpec-nano; ShimadzuBiotech). DNA samples were diluted to $50 \mathrm{ng} / \mathrm{ml}$ prior to ISSR PCRamplifications. 
Table 1. ISSR primers and GenBank acession numbers

\begin{tabular}{ccc}
\hline ISSR Primers & Sequence 5'-3' & GeneBank acession number \\
\hline ISSR 1 & $(\mathrm{AG})_{8} \mathrm{~T}$ & $\mathrm{UBC} 807$ \\
ISSR 2 & $(\mathrm{AG})_{8} \mathrm{G}$ & $\mathrm{UBC} 809$ \\
ISSR 3 & $(\mathrm{GA})_{8} \mathrm{~T}$ & $\mathrm{UBC} 810$ \\
ISSR 4 & $(\mathrm{GA})_{8} \mathrm{C}$ & $\mathrm{UBC} 811$ \\
ISSR 5 & $(\mathrm{CA})_{8} \mathrm{~A}$ & $\mathrm{UBC} 817$ \\
ISSR 6 & $(\mathrm{TC})_{8} \mathrm{C}$ & $\mathrm{UBC} 823$ \\
ISSR 7 & $(\mathrm{AC})_{8} \mathrm{C}$ & $\mathrm{UBC} 826$ \\
ISSR 8 & $(\mathrm{AG})_{8} \mathrm{CTT}$ & $\mathrm{UBC} 846$ \\
ISSR 9 & $(\mathrm{CA})_{8} \mathrm{AGT}$ & $\mathrm{UBC} 855$ \\
ISSR 10 & $(\mathrm{GT})_{8} \mathrm{CTA}$ & $\mathrm{UBC} 856$ \\
\hline
\end{tabular}

\section{ISSR (Inter Simple Sequence Repeat) analysis}

ISSR-PCR DNA amplifications (Martins-Lopes et al., 2009) were performed using ten ISRR primers (Table 1) and PCR reactions were carried in a $25 \mathrm{ml}$ reaction volume, containing PCR Buffer (1x final concentration, invitrogen), 2.5 $\mathrm{mM} \mathrm{MgCl} 2,0.4 \mathrm{mM}$ of each dNTP, $0.4 \mathrm{mM}$ ISSR primer, 50 ng genomic DNA and 2 unit Taq DNA polymerase. Amplification conditions (thermocycler Model-9700, PerkinElmer, Boston, MA, USA) were as follows: initial denaturation at $95^{\circ} \mathrm{C}$ for $3 \mathrm{~min}, 35 \mathrm{cycles}$ at $95^{\circ} \mathrm{C}$ for $15 \mathrm{sec}, 55^{\circ} \mathrm{C}$ for $30 \mathrm{sec}$, a ramp to $72^{\circ} \mathrm{C}$ reaching in $3 \mathrm{~min}$, followed by a $10 \mathrm{~min}$ lag at this temperature, and an indefinite holding at $4{ }^{\circ} \mathrm{C}$, respectively. Amplicons were separated on $1.5 \%$ agarose gel at $80 \mathrm{~V}$. They were then stained with $0.5 \mathrm{ml} / \mathrm{ml}$ ethidium bromide solution, visualized by illumination under UV light, and documented using a gel documentation and image analysis system (BIORAD, Molecular Imager, ChemiDocTM XRS+ with Image LabTM Software).

\section{Dataanalysis}

DNA fragments of ISSR PCR reactions were scored by their presence (1) or absence (0) and the ones at low intensities were scored only if they were reproducible in the PCR runs. Cluster analysis was performed to construct dendrograms, with the unweighted pair-group method by arithmetic averages (UPGMA) from the similarity data matrices using Jaccard's coefficient (Rohlf, 1998).

\section{Results and discussions}

Molecular fingerprintings of 40 clones belonging to 8 Turkish cultivars were carried out using ISSR analysis and very high polymorphism ( $94.9 \%$ polymorphism in average) was detected by the method. The total of 217 reproducible bands, ranging from 100 to $4,250 \mathrm{bp}$, were scored with the ISSR technique. The highest polymorphism rate was obtained by ISSR 3 primer which produced 27 polymorphic bands (Table 2).

Genetic similarities/varieties were obtained with UPGMA algorithm using Jaccard's coefficient. The genetic similarities ranged from 0.32 (between Mugla cv. 'Domat' clone 2 and Balikesir cv. 'Edincik' clone 5) to 0.96 (Samsun cv. 'Alacam' clone 4 and 5) (Fig. 2. A and B).

The cultivars were grouped into four clusters: Cluster I, with Balıkesir cv. 'Edincik' 1-5 and Bursa-Gemlik cv. 'Gemlik' 1-5; Cluster II, Hatay cv. 'Edremit' 1-5 and Mardin cv. 'Halhali' 1-5; Culuster III, Mugla cv. 'Domat' 1-5, Samsun cv. 'Alacam' 1-5 and cv. 'Tekir' 1-3; Cluster IV, cv. 'Tekir' 4-5 and cv. 'Yaglik' 1, 2 (Fig. 1).
Some close relationships between cultivars were constant in all ISSR analyses performed; for instance, cv. 'Edincik' and cv. 'Gemlik' (similarity ranges from 0.544 to 0.803 ); cv. 'Edremit' and 'Halhali' (similarity ranges from 0.475 to 0.658 ); cv. 'Domat' and cv. 'Alacam' (similarity ranges from 0.523 to 0.806 ) and cv. 'Tekir' with 'Yaglik' (similarity ranges from 0.480 to 0.762 ). On the other hand, the dendrogram indicated that cv. 'Tekir' clones 1,2 and 3 (Cluster III) and 'Tekir' clones 4 and 5 (Cluster IV) were in different groups. This was not surprising as there were many polymorphic bands in PCR gel analysis (Fig. 2C).

ISSR marker system has been extensively used to determine genetic relationships between numerous plant species and cultivars (Galvan et al., 2003; Martins et al., 2004; Qian et al., 2001; Uysal et al., 2010; Wiesnerova and Wiesner, 2004). However, there have been many reports on olive cultivar identification via ISSR marker techniques (Essadki et al., 2006; Gemas et al., 2004; Gomes et al., 2009; Hess et al., 2000). Accordingly, the present report is to be a comprehensive study on molecular identification of olive cultivars using ISSR molecular marker.

Although all ISSR PCR reactions produced different band profiles in all cultivars according to the agarose gel analyses, high compatibility was obtained from them and their polymorphism rate was very similar (94.9\%). The highest level of polymorphism was detected with cv. 'Yaglik' clone 3,4 and 5 by all band profiles; indeed, this cultivar was very distant from the others and was grouped into different cluster (it was found in Cluster IV of the dendrogram). This cultivar was very different from the others also by morphological characteristics; it has different fruit size from the others, high oil and low water content (Isik et al., 2011).

The dendrogram analyses almost fully matched with same clones; however, there was some evidence for clustering of clones derived from different branches. Clone cv. 'Yaglik' Y13 and Y4-5 were in different branches, while their similarity ranges were between 0.58 and 0.71 .

These differences could be the result of cross-pollination with local populations (Contento et al., 2002), somatic mutations (Belaj et al., 2004) and sometimes could also be due to the presence of a high level of homonymy in the collection. This is a significant problem and is a great risk for olive producers, as the renewal of certified orchards should be based on certified plants (Gemas et al., 2004; Hannachi et al., 2008; Martins-Lopes et al., 2007).

Classical olive certification system is based on morphological and agronomic procedures which are affected by environmental conditions, and mislabelling accessions can negatively affect certification of olive products (Hannachi et al., 2008). Molecular marker systems are of great importance to overcome such a problem, therefore is necessary to determine the polymorphism level of olive cultivars and to identify the homonymy and synonym problems in olive germplasm.

\section{Conclusions}

Determination of genetic relationships among olive cultivars eases efficient sampling, operating and using of germplasm resources. In the present study, ISSR analysis displayed a high level of genetic variability among Turkish olive cultivars, indicating a potential resource for the use of this germplasm in clonal selection programs. 
98

Table 2. Analysis of ISSR PCR band profiles

\begin{tabular}{|c|c|c|c|c|c|}
\hline Primer & Total band profiles & $\begin{array}{c}\text { Polymorphic band } \\
\text { numbers }\end{array}$ & $\begin{array}{c}\text { Monomorphic band } \\
\text { numbers }\end{array}$ & $\begin{array}{c}\text { Maximum length } \\
\text { (bp) }\end{array}$ & $\begin{array}{c}\text { Minimum length } \\
\text { (bp) }\end{array}$ \\
\hline ISSR 1 & 18 & 18 & - & 3,600 & 220 \\
\hline ISSR 2 & 25 & 23 & 2 & 4,250 & 250 \\
\hline ISSR 3 & 28 & 27 & 1 & 4,100 & 100 \\
\hline ISSR 4 & 9 & 9 & - & 3,650 & 170 \\
\hline ISSR 5 & 26 & 24 & 2 & 2,800 & 125 \\
\hline ISSR 6 & 24 & 23 & 1 & 2,900 & 125 \\
\hline ISSR 7 & 19 & 18 & 1 & 3,150 & 225 \\
\hline ISSR 8 & 24 & 23 & 1 & 3,500 & 255 \\
\hline ISSR 9 & 21 & 20 & 1 & 4,050 & 195 \\
\hline ISSR 10 & 23 & 21 & 2 & 3,800 & 125 \\
\hline TOTAL & 217 & 206 & 11 & 4,250 & 100 \\
\hline
\end{tabular}

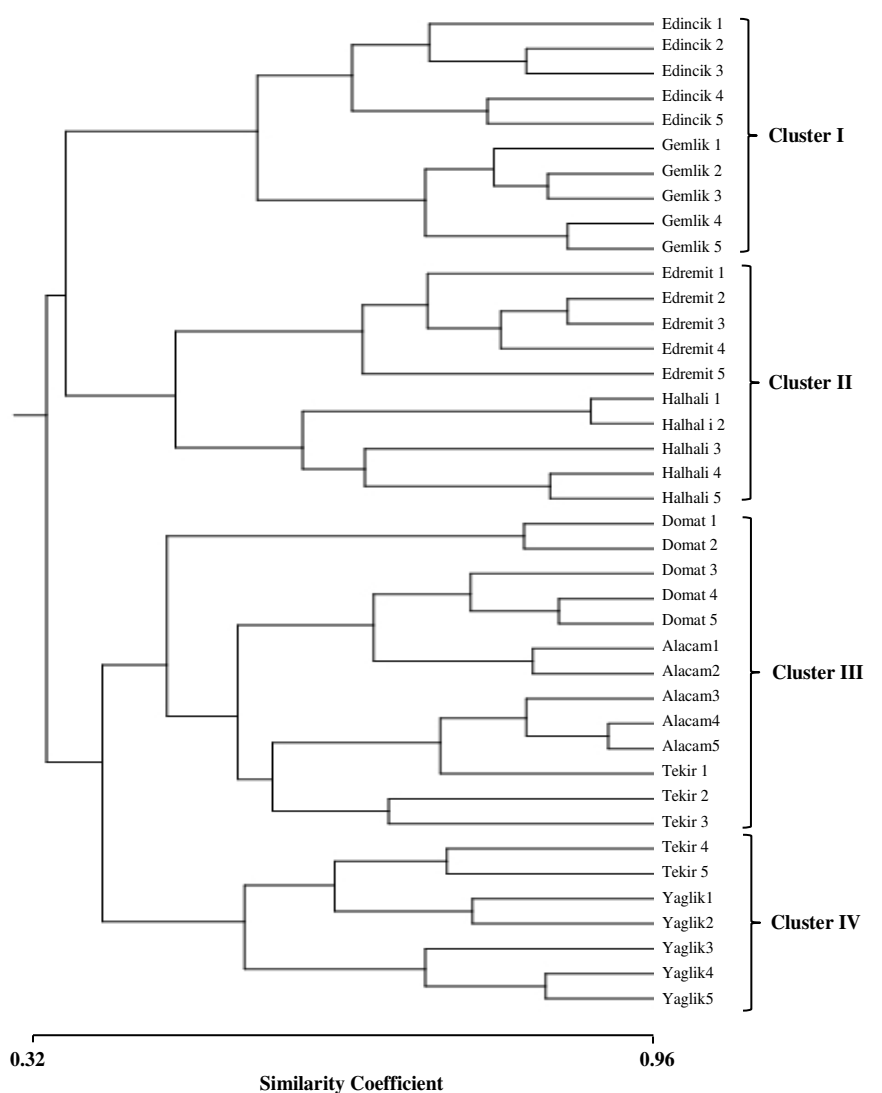

Fig. 1. UPGMA dendrogram based on Jaccard's coefficient illustrating the genetic similarities and distance among olive cultivars obtained by ISSR data, generated by the UPGMA cluster analysis (NTSYS)
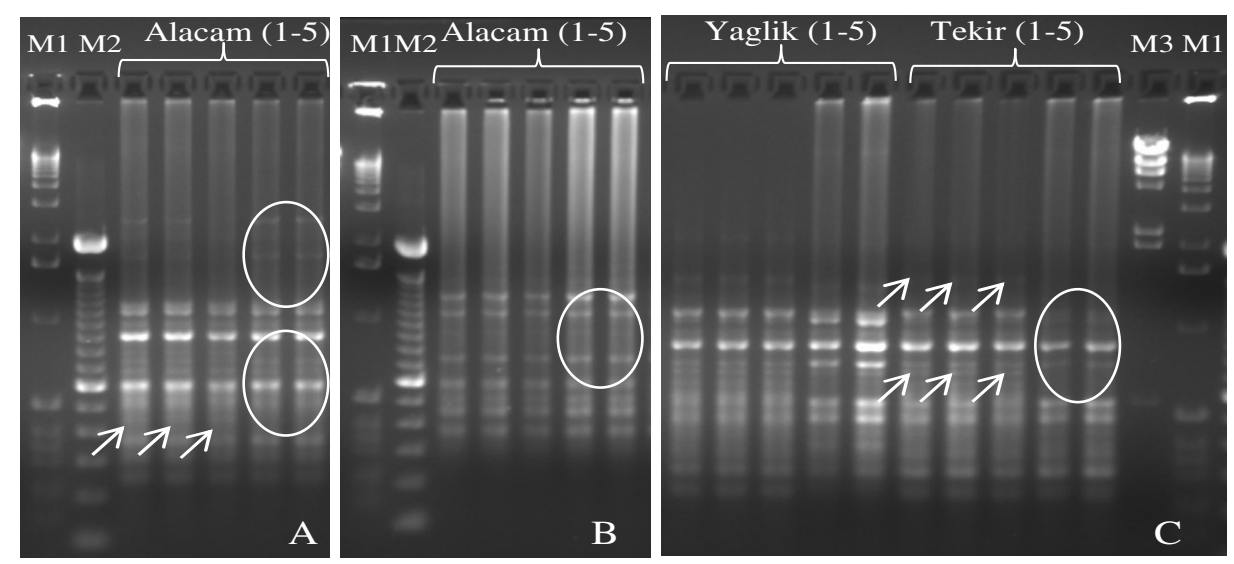

Fig. 2. Agarose gel image of PCR products using ISSR 1 (A), ISSR 3 (B) and ISSR 9 (C) primers, amplification products obtained in $1.5 \%$ agarose gel 


\section{Acknowledgements}

The study was supported by Mugla Sitki Kocman University, Scientific Research Projects Coordination Unit (Mugla,Turkey, MSKU-BAP 15-005) and Gebze Technical University, Molecular Biology and Genetics Department, Plant Biotechnology Laboratory (Kocaeli,Turkey).

\section{References}

Angiolillo A, Mencuccini M, Baldoni L (1999). Olive genetic diversity assessed using amplified fragment length polymorphisms. Theor Appl Genet 98:411-421.

Bartolini G, Prevost G, Messeri C, Carignani G (2005). Olive germplasm: cultivars and word-wide collections. Seed and Plant Genetic Resources Service-AGPS.http://www.apps3.fao.org/wiews/olive/oliv.jsp.

Belaj A, Rallo L, Trujillo I, Baldoni L (2004). Using RAPD and AFLP markers to distinguish individuals obtained by clonal selection of 'Arbequina' and 'Manzanila de Sevilla' olive. HortScience 39:15661570.

Contento A, Ceccarelli M, Gelati M, Maggini F, Baldoni L, Cionini P (2002). Diversity of Olea genotypes and the origin of cultivated olives. Theor Appl Genet 104:1229-1238.

Diaz A, Martin A, Rallo P, De la Rosa R (2006). Self- and crossincompatibility mechanisms: a strategy to ensure a great variability in olive (Olea europaea L.) populations. Olea 25:29-33.

Doyle JJ, Doyle JL (1987). A rapid DNA isolation procedure for small quantities of fresh leaf tissue. Focus 12:13-15.

Essadki M, Ouazzani O, Lumaret R, Moumni M (2006). ISSR variation in olive-tree cultivars from Morocco and other western countries of the Mediterranean Basin. Genet Res Crop Evol 53:475-482.

Fiorino P, Rallo L (1999). Proceedings of the International Seminar Genetic Resources, Florence, Italy, pp 1-24.

Galvan MZ, Bornet B, Balatti PA, Branchard M (2003). Inter simple sequence repeat (ISSR) markers as a tool for the assessment of both genetic diversity and gene pool origin in common bean (Phaseolus vulgaris L.). Euphytica 132:297-301.

Gemas VJV, Almadanim MC, Tenreiro R, Martins A, Fevereiro P (2004). Genetic diversity in the olive tree (Olea europaea L. subsp. europaea) cultivated in Portugal revealed by RAPD and ISSR markers. Genet Resour Crop Evol 51:501-511.

Gomes S, Martins-Lopes P, Lopes J, Guedes-Pinto H (2009). Assessing genetic diversity in Olea europaea L. using ISSR and SSR markers. Plant Mol Biol Rep 27:365-373.

Gomes S, Martins-Lopes P, Lima-Brito J, Meirinhos J, Lopes J, Martins A, Guedes-Pinto H (2008). Evidence for clonal variation in 'Verdeal-Transmontana' olive using RAPD, ISSR and SSR markers. J Hort Sci Biotechnol 83:395-400.

Green PS (2002). A revision of Olea L. (Oleaceae). Kew Bulletin 57:91140.
Hannachi H, Breton C, Msallem M, Ben El Hadj S, El Gazzah M, Berville A (2008). Differences between native and introduced olive cultivars as revealed by morphology of drupes, oil composition and SSR polymorphisms: a case study in Tunisia. Scientia Horticulturae 116: 280-290.

Hess J, Kadereit W, Vargas P (2000). The colonization history of Olea europaea L. in Macaronesia based on internal transcribed spacer 1 (ITS-1) sequences, randomly amplified polymorphic DNAs (RAPD), and intersimple sequence repeats (ISSR). Mol Ecol 9:857868.

Isik N, Doganlar S, Frary A (2011). Genetic diversity of Turkish olive varieties assessed by Simple Sequence Repeat and Sequence-Related Amplified Polymorphism markers. Crop Sci 51:1646-1654.

Martins M, Sarmento D, Oliveira MM (2004). Genetic stability of micropropagated almond plantlets, as assessed by RAPD and ISSR markers. Plant Cell Rep 23:492-496.

Martins-Lopes P, Gomes S, Lima-Brito J, Lopes J, Guedes-Pinto H (2009). Assessment of clonal genetic variability in Olea europaea L. 'Cobrançosa' by molecular markers. Scientia Horticulturae 123:8289.

Martins-Lopes P, Lima-Brito J, Gomes S, Meirinhos J, Santos L, Guedes-Pinto H (2007). RAPD and ISSR molecular markers in Olea europaea L.: genetic variability and molecular cultivar identification. Genet Res Crop Evol 54:117-128.

Qian W, Ge S, Hong DY (2001). Genetic variation within and among populations of a wild rice Oryza granulate from China detected by RAPD and ISSR markers. Theor Appl Genet 102:440-449.

Rallo P, Dorado G, Martin A (2000). Development of simple sequence repeats (SSRs) in the olive tree (Olea europaea L.). Theor Appl Genet 101:984-989.

Rohlf FJ (1998). NTSYS-pc numerical taxonomy and multivariate analysis system version 2. 0. Exeter Publications, New York, USA.

Rugini E, Lavee S (1992). Olive. In: Biotechnology of perennial fruit crops. Hammerschlag FA, Litz RE (Eds), CAB Int., Wellingford, UK, pp 371-382.

Terzopoulos PJ, Kolano B, Bebeli PJ, Kaltsikes PJ, Metzidakis I (2005). Identification of Olea europaea L. cultivars using inter-simple sequence repeat markers. Scientia Horticulturae 105:45-51.

Uysal H, Fu YB, Kurt O, Peterson GW, Diederichsen A, Kusters P (2010). Genetic diversity of cultivated flax (Linum usitatissimum L.) and its wild progenitor pale flax (Linum bienne Mill.) as revealed by ISSR markers. Genet Resour Crop Evol 57:1109-1119.

Wiesnerova D, Wiesner I (2004). ISSR-based clustering of cultivated flax germplasm is statistically correlated to thousand seed mass. Mol Biotechnol 26:207-214.

Zohary D, Hopf M (1994). Domestication of plants in the Old World (2ndEd.). Clarendon Press, Oxford, UK. 